Folia Cardiologica 2017 tom 12, nr 1, strony 96-102 DOI: $10.5603 /$ FC.2017.0012 Copyright (c) 2017 Via Medica ISSN 2353-7752

\title{
Zawał serca z uniesieniem odcinka ST u młodej kobiety z trombofilią złożoną
}

\author{
Myocardial infarction with ST-elevation in a young woman \\ with complex thrombophilia
}

\author{
Anna Kowalczys ${ }^{1}$, Andrzej Mital ${ }^{2}$, Katarzyna Storoniak ${ }^{1}$, Marcin Gruchała ${ }^{1}$ \\ ${ }^{1}$ I Katedra i Klinika Kardiologii Gdańskiego Uniwersytetu Medycznego \\ ${ }^{2}$ Katedra i Klinika Hematologii i Transplantologii Gdańskiego Uniwersytetu Medycznego
}

\section{Streszczenie}

Chorą w wieku 31 lat przyjęto do kliniki z powodu silnego bólu w klatce piersiowej. Na podstawie obrazu klinicznego i wyników badań dodatkowych rozpoznano zawał serca z uniesieniem odcinka ST. W trybie pilnym wykonano koronarografię, a następnie rekanalizację zamkniętej gałęzi przedniej zstępującej z implantacją stentu uwalniającego zotarolimus, uzyskując poprawę kliniczną. Wśród czynników ryzyka miażdżycy stwierdzono nadciśnienie tętnicze i hipercholesterolemię. Ze względu na młody wiek chorej zlecono badania w kierunku trombofilii, w których potwierdzono hiperhomocysteinemię, mutację genu MTHFR, niedobór białka S i zwiększone stężenie czynnika VIII. W związku z podwyższonym ryzykiem nawrotu powikłań zakrzepowo-zatorowych do podwójnej terapii przeciwpłytkowej dołączono riwaroksaban. Poniższy przypadek skłania ku wnikliwemu poszukiwaniu dodatkowych czynników ryzyka u młodych chorych z zawałem serca w celu wdrożenia optymalnej prewencji wtórnej zdarzeń sercowo-naczyniowych.

Słowa kluczowe: zawał serca, trombofilia złożona, hiperhomocysteinemia, mutacja genu MTHFR, niedobór białka S, leczenie przeciwkrzepliwe

Folia Cardiologica 2017; 12, 1: 96-102

\section{Wstęp}

Ostre zespoły wieńcowe (ACS, acute coronary syndromes) u chorych poniżej 45. roku życia występują stosunkowo rzadko, stanowiąc 6-10\% wszystkich zawałów serca (MI, myocardial infarctions), i dotyczą głównie mężczyzn. Najczęstszą przyczyną ACS w młodym wieku jest miażdżyca tętnic wieńcowych. Niemniej jednak istnieje wiele innych schorzeń i czynników ryzyka, które mogą sprzyjać jego wystąpieniu, na przykład zaburzenia hemostazy, zator do tętnic wieńcowych, anomalie tętnic wieńcowych, zapalenia tętnic, toczeń rumieniowaty układowy, antykoncepcja doustna i inne [1]. Poniżej przedstawiono przypadek kliniczny 31-letniej chorej przyjętej do kliniki kardiologii z klinicznego oddziału ratunkowego (KOR) z rozpoznaniem zawału serca z uniesieniem odcinka ST (STEMI, ST-elevation myocardial infraction) ściany przednio-bocznej.

\section{Opis przypadku}

\section{Badanie podmiotowe i przedmiotowe}

W dniu przyjęcia do kliniki chora zgłosiła typowy, silny, spoczynkowy ból zamostkowy, promieniujący do kończyny górnej lewej. Dzień wcześniej wystąpiły po raz pierwszy w życiu tej pacjentki wysiłkowe bóle zamostkowe o niewielkim nasileniu. W wywiadzie stwierdzono nadciśnienie tętnicze 
leczone od 2 lat nebiwololem w dawce $2,5 \mathrm{mg} /$ dobę. Chora negowała obecność innych dolegliwości i schorzeń towarzyszących, nałogów oraz alergii. Nie była wcześniej poddana żadnym zabiegom ani operacjom. Wywiad rodzinny był nieistotny. Chora od 13 lat stosowała antykoncepcję hormonalną, przez ostatnie 2 lata złożoną z drospirenonu i etynyloestradiolu.

Przy przyjęciu chora była wydolna krążeniowo-oddechowo, z dobrym kontaktem słowno-logicznym; odczuwała silny, spoczynkowy ból zamostkowy bez towarzyszącej duszności. W badaniu przedmiotowym stwierdzono: ciśnienie tętnicze $120 / 80 \mathrm{~mm} \mathrm{Hg}$, tętno miarowe 90/min, saturację $0_{2}$ równą $98 \%$, temperaturę ciała $36,6^{\circ} \mathrm{C}$; osłuchowo nad polami płucnymi prawidłowy szmer pęcherzykowy; czyste, dźwięczne i prawidłowo akcentowane tony serca; miękki, niebolesny brzuch, bez oporów patologicznych z obecną perystaltyką, niepowiększone wątrobę i śledzionę. Nie zaobserwowano obrzęków kończyn dolnych ani cech zakrzepicy żylnej, objaw Homansa był obustronnie ujemny. Wzrost pacjentki wynosił $169 \mathrm{~cm}$, masa ciała - $55 \mathrm{~kg}$, a wskaźnik masy ciała (BMI, body mass index) $-19 \mathrm{~kg} / \mathrm{m}^{2}$.

\section{Badania dodatkowe, dalsze postępowanie i leczenie}

Wyniki badań laboratoryjnych krwi wykonanych przy przyjęciu i w trakcie leczenia w klinice przedstawiono w tabeli 1. Zwracają uwage znacząco podwyższone wartości markerów martwicy mięśnia sercowego. W badaniu ogólnym moczu pH wynosiło 5,5 (5,0-8,0), a ciężar właściwy moczu był nieco obniżony, do 1,014 g/ml (1,018-1,030 g/ml), poza tym bez istotnych odchyleń od normy. W badaniu elektrokardiograficznym (EKG) odnotowano miarowy rytm zatokowy około 65/min, normogram, uniesienia odcinka ST w odprowadzeniach V1-V6, a także w I i aVL oraz przeciwstawne obniżenia odcinka ST w odprowadzeniach II, III, aVF. Nie stwierdzono cech przeciążenia komór ani zaburzeń rytmu i przewodzenia (ryc. 1). Chora na KOR otrzymała kwas acetylosalicylowy (ASA, acetylsalicylic acid) w dawce $300 \mathrm{mg}$ doustnie (p.o., per os), klopidogrel w dawce $600 \mathrm{mg}$ p.o. oraz $5000 \mathrm{j}$. heparyny niefrakcjonowanej w bolusie, a następnie $1000 \mathrm{j} . / \mathrm{h}$ we wlewie ciągłym. W trybie pilnym skierowano chorą do pracowni hemodynamicznej, gdzie z dostępu przez prawą tętnice promieniową wykonano koronarografię, uwidaczniając: drożny i pozbawiony istotnych przewężeń pień lewej tętnicy wieńcowej (LM, left main), zamkniętą w segmencie proksymalnym gałąź przednią zstępującą (LAD, left anterior descending), drożną i bez istotnych przewężeń gałąź okalającą (Cx, circonflexe), drożną i bez istotnych przewężeń prawą tętnicę wieńcową (RCA, right coronary artery). Następnie przystąpiono do rekanalizacji LAD podano bolus abciximabu (13,75 mg; 0,25 mg/kg mc.), poszerzono balonem zwężenie w proksymalnej części LAD oraz implantowano stent powlekany zotarolimusem, uzyskując dobry efekt angiograficzny, z przepływem TIMI (Thrombolysis In Myocardial Infarction) równym 3 i bez stenozy rezydualnej (ryc. 2). Po zabiegu zaobserwowano szybką poprawę stanu klinicznego chorej; znaczne zmniejszenie, a następnie ustąpienie dolegliwości dławicowych, ewolucję zmian w EKG ze stopniową normalizacją odcinka ST, odwróceniem załamka T oraz powstaniem zespołu QS w odprowadzeniach V1-V3 (ryc. 3), a także stopniową normalizację wartości markerów martwicy mięśnia sercowego. Po zabiegu w klinice zastosowano następujące leczenie: ASA $(75 \mathrm{mg} / \mathrm{d}$.), klopidogrelem $(75 \mathrm{mg} / \mathrm{d}$.), atorwastatyną $(80 \mathrm{mg} / \mathrm{d}$.), ramiprilem $(1,25 \mathrm{mg} / \mathrm{d}$.), nebiwololem $(2,5 \mathrm{mg} / \mathrm{d}$.), pantoprazolem $(20 \mathrm{mg} / \mathrm{d}$.), enoksaparyną (0,4 ml/d. podskórnie). W badaniu echokardiograficznym uwidoczniono: akinezę koniuszka i wszystkich segmentów koniuszkowych lewej komory, akineze całej przegrody międzykomorowej z wyjątkiem segmentu podstawnego dolnej części przegrody (normokineza), akinezę segmentu środkowego i hipokineze segmentu podstawnego ściany przedniej, hipokinezę segmentu środkowego i normokinezę segmentu podstawnego ściany dolnej, hipokinezę segmentu środkowego i hiperkinezę segmentu podstawnego ściany tylnej i bocznej; frakcja wyrzutowa lewej komory (LVEF, left ventricular ejection fraction) wyniosła około $40 \%$. Wielkość jam serca oraz budowa i funkcja zastawek tętnicy płucnej, aortalnej, mitralnej i trójdzielnej były prawidłowe. Uwidoczniono żyłę główną dolną prawidłowo zapadającą się na wdechu. W worku osierdziowym nie stwierdzono płynu.

W trakcie hospitalizacji chora była monitorowana, w analizowanych zapisach telemetrycznych nie zaobserwowano istotnych klinicznie zaburzeń rytmu i przewodzenia. Przeprowadzono 24-godzinny pomiar ciśnienia tętniczego, w którym stwierdzono prawidłowe wartości ciśnienia świadczące o skuteczności dotychczasowego postępowania. W badaniu radiologicznym (RTG) klatki piersiowej uwidoczniono zacienienie o średnicy $20 \mathrm{~mm}$ w polu środkowym prawego płuca, poza tym płuca były pozbawione zgęszczeń miąższowych, o prawidłowym rysunku naczyniowym, a jamy opłucnowe wolne. W związku z powyższym wykonano tomografię komputerową (CT, computed tomography) klatki piersiowej bez podania środka kontrastowego (chora nie wyraziła na to zgody), w którym nie uwidoczniono zmian o cechach rozrostowych w miąższu płuc, stwierdzono natomiast nieokreśloną zmianę w lewej nerce, kilka zmian torbielowatych oraz zwapnienie w wątrobie. W celu wyjaśnienia charakteru zmiany w nerce wykonano badanie ultrasonograficzne (USG) jamy brzusznej, w którym potwierdzono obecność zmian o charakterze torbieli w lewej nerce oraz kilku torbieli w wątrobie. Ponadto wykonano USG tętnic szyjnych metodą Doplera, w którym nie uwidoczniono istotnych hemodynamicznie zwężeń w badanych tętnicach. W związku z podejrzeniem zaburzeń układu hemostazy chorą konsultowano hematologicznie. Wykonano panel badań w kierunku trombofilii (tab. 2). Na podstawie otrzymanych 
Tabela 1. Wyniki badań laboratoryjnych krwi chorej wykonanych przy przyjęciu do kliniki

\begin{tabular}{|c|c|c|}
\hline Parametr & Wynik & Wartości referencyjne \\
\hline Stężenie hemoglobiny [g/dl] & 13,0 & $12-15$ \\
\hline Liczba krwinek czerwonych [T/I] & 4,0 & $3,8-4,8$ \\
\hline Odsetek hematokrytu (\%) & 36 & $36-45$ \\
\hline MCV [fl] & 90 & $80-96$ \\
\hline Liczba płytek krwi [G/I] & 280 & $150-410$ \\
\hline Liczba krwinek białych [G/I] & 14,1 & $4,0-10$ \\
\hline Liczba limfocytów [G/I] & 3,31 & $1,0-3,0$ \\
\hline Liczba neutrocytów [G/I] & 9,6 & $2,0-7,0$ \\
\hline Liczba monocytów [G/I] & 0,8 & $0,2-1,0$ \\
\hline Liczba eozynocytów [G/I] & 0,31 & $0,02-0,5$ \\
\hline Czas protrombinowy [s] & 12 & $10-15$ \\
\hline INR & 1,01 & $0,9-1,3$ \\
\hline APTT [s] & 27 & $26-37$ \\
\hline Współczynnik APTT & 0,82 & $0,8-1,2$ \\
\hline Stężenie fibrynogenu [g/l] & 1,91 & $1,8-3,5$ \\
\hline Stężenie D-dimerów [ug/l] & 157,5 & $<250$ \\
\hline Stężenie AspAT [j./l] & 27 & $5-34$ \\
\hline Stężenie AIAT [j./I] & 14 & $0-55$ \\
\hline Stężenie kinazy kreatynowej [j./l] & 63 & $29-168$ \\
\hline Stężenie LDH [j./I] & 504 & $125-220$ \\
\hline Stężenie bilirubiny całkowitej [mg/dl] & 0,3 & $0,1-1,2$ \\
\hline Stężenie CRP [mg/dl] & 0,86 & $<5$ \\
\hline Stężenie azotu mocznika [mg/dl] & 12,0 & $7-18,7$ \\
\hline Stężenie kreatyniny [mg/dl] & 0,86 & $0,55-1,2$ \\
\hline GFR $\left[\mathrm{ml} / \mathrm{min} / 1,73 \mathrm{~m}^{2}\right]$ & $>60$ & $>60$ \\
\hline Stężenie sodu [mEq/l] & 141 & $135-145$ \\
\hline Stężenie potasu [mEq/l] & 4,4 & $3,5-5,1$ \\
\hline Glikemia [mg/dl] & 138 & $60-99$ \\
\hline 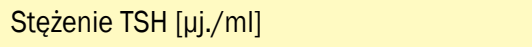 & 0,88 & $0,34-4,94$ \\
\hline Stężenie hsTnl [ng/ml] & 76,7 & $<0,01$ \\
\hline Stężenie CKMB [ng/ml] & 281,7 & $0,00-6,6$ \\
\hline Stężenie BNP [pg/ml] & 295 & $<89$ \\
\hline Stężenie cholesterolu całkowitego [mg/dl] & 204 & $<170$ \\
\hline Stężenie triglicerydów [mg/dl] & 111 & $<150$ \\
\hline Stężenie cholesterolu frakcji HDL [mg/dl] & 51 & $>45$ \\
\hline Stężenie cholesterolu frakcji LDL [mg/dl] & 131 & $<70$ \\
\hline
\end{tabular}

Pogrubioną czcionką wyróżniono parametry odbiegające od wartości prawidłowych; MCV (mean corpuscular volume) - średnia objętość krwinki; INR (international normalized ratio) - międzynarodowy wskaźnik znormalizowany; APTT (activated partial thromboplastin time) - czas częściowej tromboplastyny po aktywacji; AspAT (aspartate aminotransferase) - aminotransferaza asparaginowa, AIAT (alanine aminotransferase) - aminotransferaza alaninowa; LDH (lactate dehydrogenase) - dehydrogenaza mleczanowa; CRP (C-reactive protein) - białko C-reaktywne, GFR (glomerular filtration rate) - współczynnik filtracji kłębuszkowej; TSH (thyrotropin-stimulating hormone) - hormon tyreotropowy; hsTnl (high-sensitivity troponine I) - troponina I wysokiej czułości; CKMB (creatnine kinase myocardial bound isoenzyme) - izoenzymy sercowe kinazy kreatynowej; BNP (B-type natriuretic peptide) - peptyd natriuretyczny typu B; HDL (high-density lipoprotein) - lipoproteiny o wysokiej gęstości; LDL (low-density lipoprotein) - lipoproteiny o niskiej gęstości 


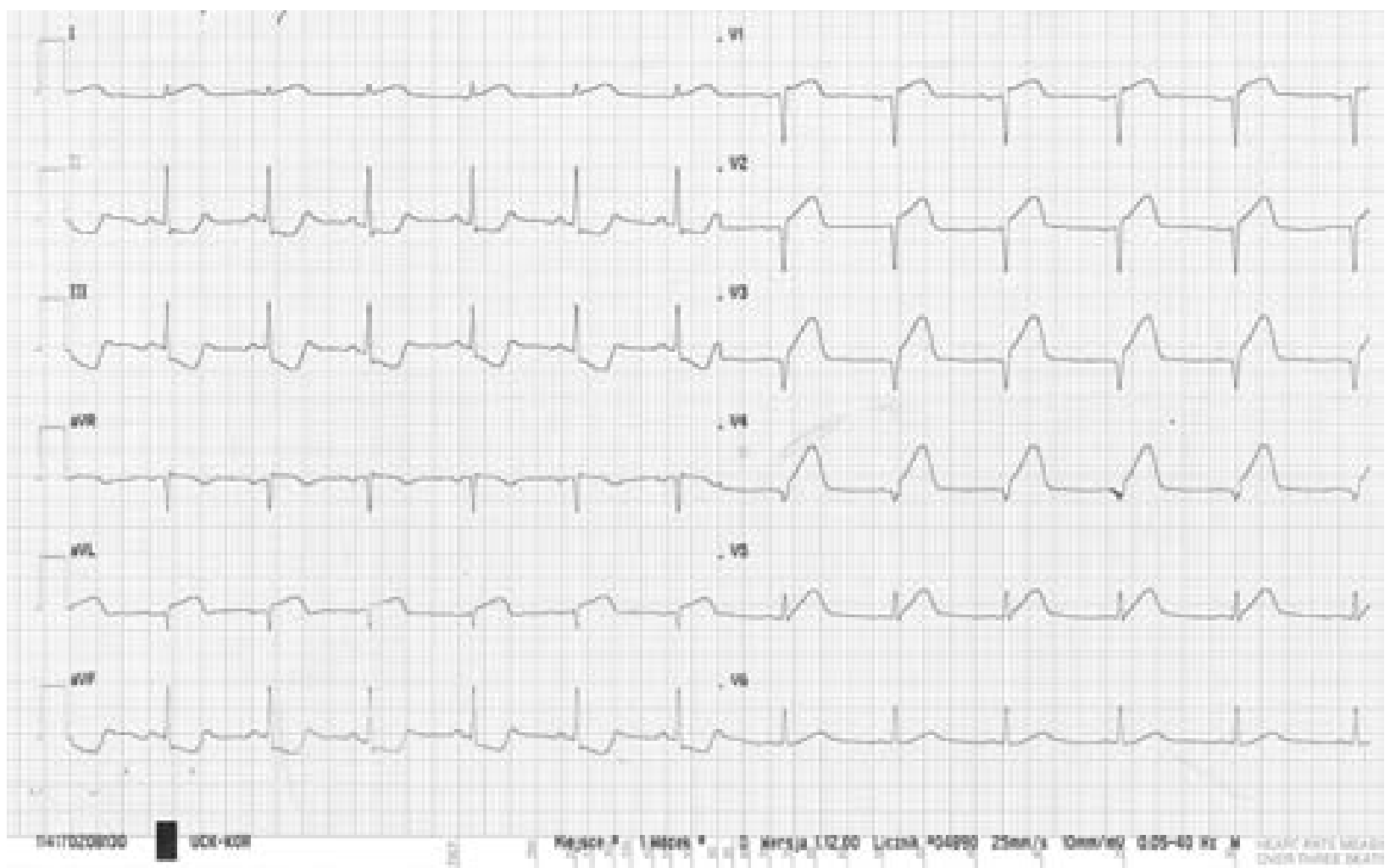

Rycina 1. Badanie elektrokardiograficzne przy przyjęciu chorej do kliniki
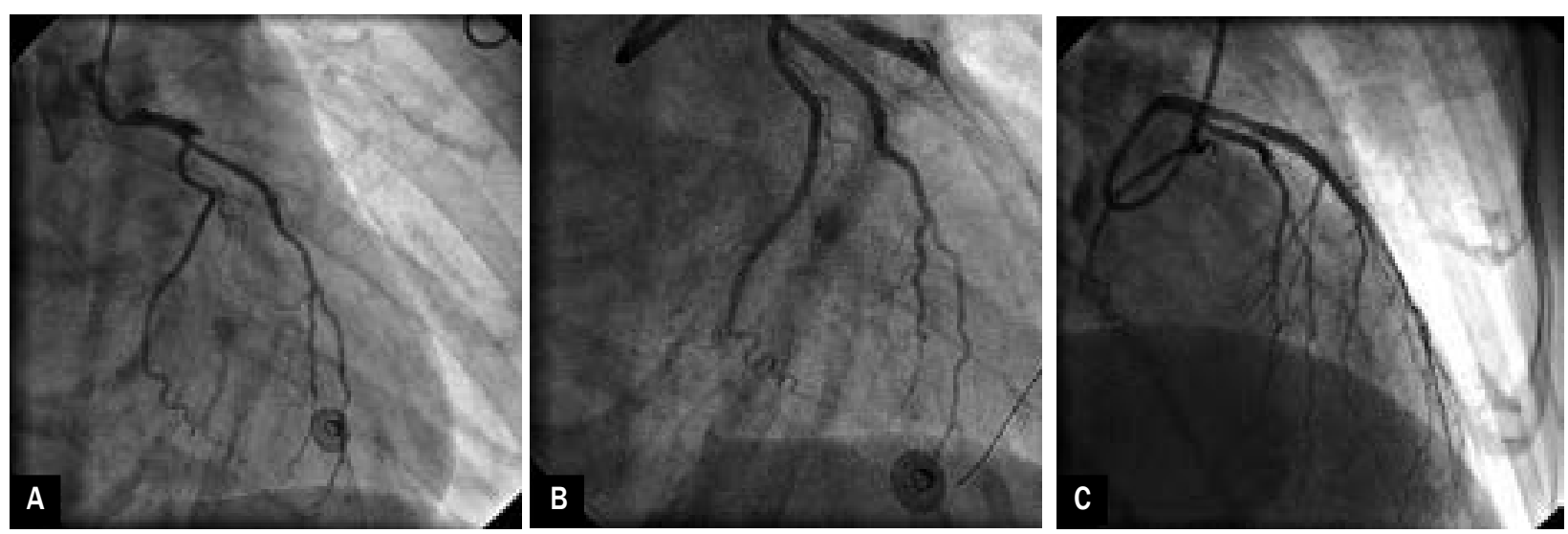

Rycina 2A-C. Badanie koronarograficzne uwidaczniające zamkniętą gałąź przednią zstępującą (LAD, left anterior descending) (A) i rekanalizacja LAD z implantacją stentu powlekanego lekiem (B, C)

wyników rozpoznano trombofilię złożoną z następujących zaburzeń: hiperhomocysteinemii, mutacji genu MTHFR C677T (heterozygota), niedoboru białka S, podwyższonego stężenia czynnika VIII. Ze względu na wysokie ryzyko nawrotu powikłań zakrzepowo-zatorowych, po dokładnym rozważeniu ryzyka wystąpienia krwawienia (2 pkt. w skali HAS-BLED), zdecydowano o rozpoczęciu leczenia przeciw- krzepliwego nowym doustnym antykoagulantem (NOAC, new oral anticoagulant) z grupy bezpośrednich inhibitorów czynnika Xa - riwaroksabanem. W leczeniu początkowym zastosowano riwaroksaban w dawce $15 \mathrm{mg} /$ dobe, zalecając jej zwiększenie do $20 \mathrm{mg} /$ dobę po upływie 3 tygodni. $\mathrm{Z}$ powodu hiperhomocysteinemii dołączono kwas foliowy w dawce $15 \mathrm{mg} /$ dobę. 


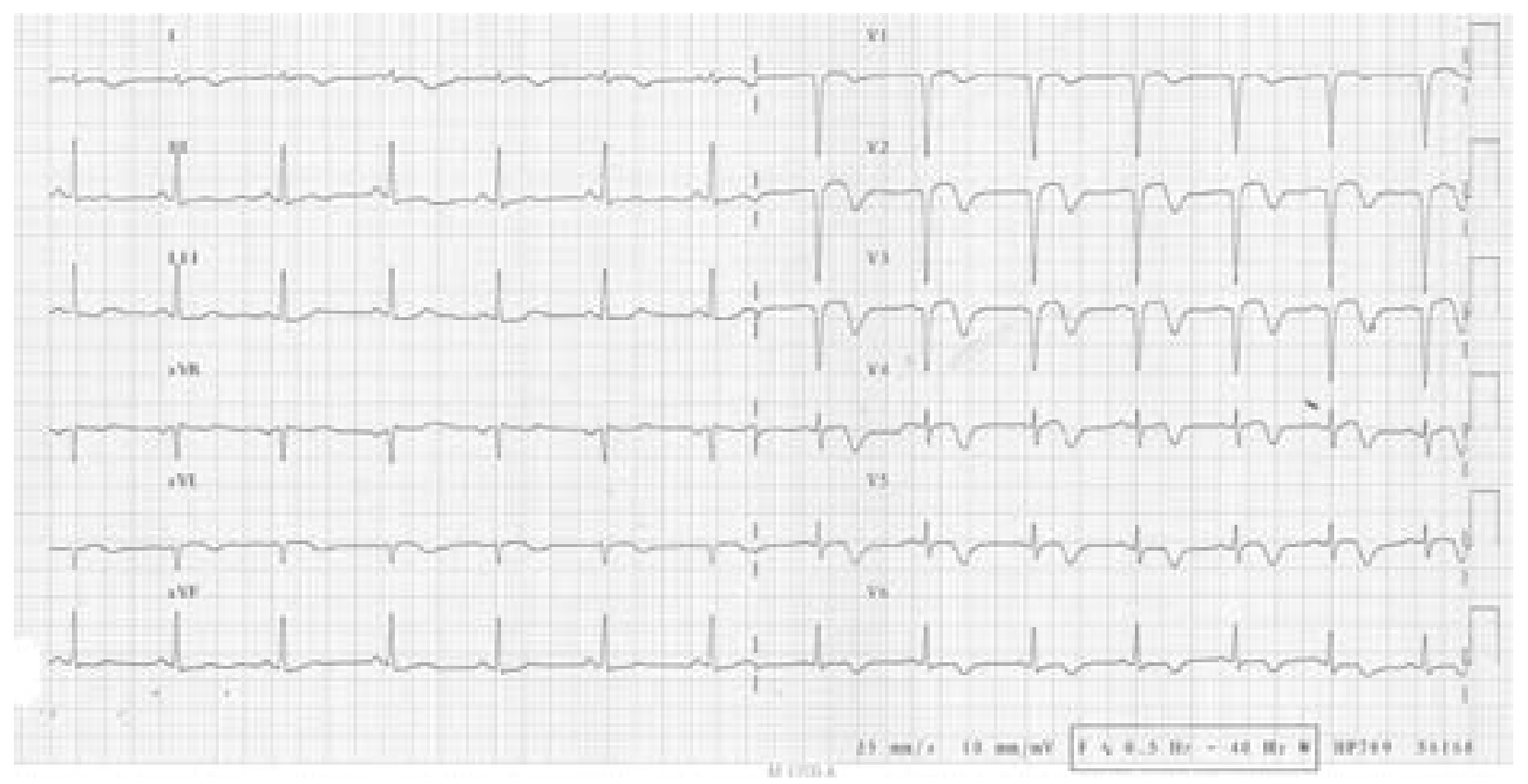

Rycina 3. Badanie elektrokardiograficzne wykonane po rekanalizacji gałęzi przedniej zstępującej (LAD, left anterior descending) i ustabilizowaniu stanu klinicznego chorej

\section{Rozpoznanie ostateczne}

Na podstawie typowego wywiadu, współistniejących objawów klinicznych oraz wyników badań i konsultacji rozpoznano: STEMI, dysfunkcję skurczową lewej komory (EF ok. 40\%), trombofilię złożoną (hiperhomocysteinemia, mutacja genu MTHFR C677T - heterozygota, niedobór białka S, podwyższony czynnik VIII), nadciśnienie tętnicze, hipercholesterolemię, torbiele nerek i wątroby.

\section{Końcowe zalecenia}

Po ustabilizowaniu stanu chorej i uzyskaniu poprawy, przy wypisywaniu z kliniki, chorą skierowano na rehabilitacje kardiologiczną. Zalecono regularne kontrole w poradniach kardiologicznej i zaburzeń hemostazy. Ponadto zalecono regularną kontrolę ciśnienia tętniczego i rytmu serca w warunkach ambulatoryjnych oraz dietę ubogocholesterolową. Pouczono chorą o konieczności rezygnacji z doustnej antykoncepcji hormonalnej i zastosowania metod zapobiegania ciąży uzgodnionych z prowadzącym lekarzem ginekologiem. Zalecono kontynuację leczenia farmakologicznego wdrożonego w klinice i złożonego z ASA (75 mg/d.), klopidogrelu $(75 \mathrm{mg} / \mathrm{d}$.), riwaroksabanu ( $15 \mathrm{mg} / \mathrm{d}$. przez 3 tygodnie, a następnie $20 \mathrm{mg} / \mathrm{d}$.) atorwastatyny $(80 \mathrm{mg} / \mathrm{d}$.), ramiprilu (1,25 mg/d.), nebiwololu (2,5 mg/d.), pantoprazolu (20 mg/d.) oraz kwasu foliowego (15 mg/d.).

\section{Omówienie}

Powikłania zakrzepowo-zatorowe w młodym wieku powinny zawsze skłaniać do diagnostyki w kierunku trombofilii. Mia- nem trombofilii określa się wrodzoną lub nabytą skłonność do zakrzepicy. Choroba może przebiegać bezobjawowo przez wiele lat, nierzadko jej pierwszą manifestacją jest żyIna choroba zakrzepowo-zatorowa (VTE, venous thromboembolism). Szacuje się, że u 20-50\% chorych z pierwszym epizodem zakrzepicy występuje mutacja Leiden [2]. Ryzyko powikłań zakrzepowo-zatorowych jest najwyższe w przypadku niedoboru antytrombiny oraz białek C i S, a umiarkowane w przypadku obecności mutacji Leiden i genu protrombiny G20210A. W wywiadzie należy zwrócić szczególną uwagę na poronienia nawykowe, nawracającą zakrzepice, zakrzepicę o nietypowej lokalizacji, zakrzepice tętniczą, dodatni wywiad rodzinny w kierunku VTE.

Trombofilia sprzyja występowaniu VTE, niemniej jednak może stanowić jedną z przyczyn zakrzepicy tętniczej, zwłaszcza w postaci złożonej, jak w opisanym przypadku. Według niektórych autorów ryzyko obecności przynajmniej jednego zaburzenia z grupy trombofilii jest szczególnie wysokie w grupie młodych chorych z MI [3]. Hiperhomocyteinemia wiąże się z częstszym występowaniem choroby wieńcowej ze względu na niekorzystny wpływ homocysteiny na śródbłonek i proliferację mięśni gładkich naczyń. Istnieją również doniesienia o wpływie podwyższonego stężenia homocysteiny na śmiertelność sercowo-naczyniową u chorych poniżej 50. roku życia [1]. Kim i wsp. [4] wykazali w swojej metaanalizie związek między obecnością mutacji Leiden, genu protrombiny G20210A i mutacji genu MTHFR C677T a wzrostem ryzyka wystąpienia MI i udaru mózgu zwłaszcza u młodych kobiet [4]. Inni autorzy również potwierdzili związek mutacji genu MTHFR C677T z wyższym ryzykiem 
Tabela 2. Wyniki badań diagnostycznych w kierunku trombofilii

$\begin{array}{lcc}\text { Parametr } & \text { Wynik } & \text { Wartości referencyjne } \\ \text { Stężenie białka C (\%) } & 117 & 70-140 \\ \text { Współczynnik APC-R } & 2,15 & 2,00 \\ \text { Stężenie białka S (\%) } & 40 & 60-130 \\ \text { Stężenie czynnika VIII (\%) } & 200 & 70-150 \\ \text { Stężenie antytrombiny III (\%) } & 85 & 75-125 \\ \text { Mutacja genu protrombiny G20210A } & \text { Nie wykryto } & <5,00 \\ \text { Mutacja genu MTHFR } & \text { Heterozygota C677T } & <5,00 \\ \text { Miano przeciwciał przeciwko } \beta_{2} \text {-glikoproteinie lgM [j./ml] } & 1,68 & <7 \\ \text { Miano przeciwciał przeciwko } \beta_{2} \text {-glikoproteinie IgG [j./ml] } & 1,17 & \text { Wynik negatywny } \\ \text { Miano przeciwciał przeciwko kardiolipinie IgM [j./ml] } & 0,74 & <10 \\ \text { Miano przeciwciał przeciwko kardiolipinie IgG [j./ml] } & & \text { Wynik negatywny } \\ \text { Przeciwciała przeciwjądrowe ANA-Hep-2 } & 0,88 & <1: 80 \\ & & 31-44 \\ \text { LA1 dRVT [s] } & 1: 80 & 33-45 \\ \text { LA aPTT [s] } & \text { Typ ziarnisty } & 4,9-15\end{array}$

Pogrubioną czcionką wyróżniono parametry odbiegające od wartości prawidłowych; APC-R (activated protein C resistance) - oporność na aktywowane białko C; MTHFR (methylenetetrahydrofolate reductase) - reduktaza metylenotetrahydrofolianowa; IgM - immunoglobulina M; IgG - immunoglobulina G; LA1 dRVVT (Iupus anticoagulant dilute Russel's viper venom time) - antykoagulant tocznia wykrywany na podstawie czasu krzepnięcia aktywowany jadem żmii Russela; LA aPTT (lupus anticoagulat activated partial thromboplastin time) - antykoagulant tocznia wykrywany na podstawie czasu częściowej protrombiny po aktywacji

wystąpienia MI u młodych chorych [5, 6]. Tym niemniej powyższe obserwacje wymagają potwierdzenia w dalszych badaniach. Ponadto istnieją także doniesienia wskazujące na to, że izolowany niedobór białka S może być niezależnym czynnikiem ryzyka zakrzepicy tętniczej [7]. W opisanym przypadku należy zwrócić uwagę na kolejny czynnik ryzyka powikłań zakrzepowo-zatorowych, jakim była doustna złożona antykoncepcja (COC, combined oral contraceptive) stosowana przez chora od 2 lat. Liczne doniesienia wskazują na co najmniej 3-4-krotny, zależny od dawki leków, wzrost ryzyka VTE u kobiet stosujących COC [8, 9]. Ryzyko wystąpienia powikłań zakrzepowo-zatorowych jest wyższe u stosujących COC niż u przyjmujących progestageny drugiej generacji. Współwystępowanie kilku czynników ryzyka, zwłaszcza przebytej VTE, czy obecność trombofilii jest względnym wskazaniem do zaprzestania stosowania COC, co zalecono chorej.

Współistnienie złożonej trombofilii z nadciśnieniem tętniczym, hipercholesterolemią i doustną antykoncepcja w wywiadzie znacząco podwyższa ryzyko nawrotu powikłań zakrzepowo-zatorowych u przedstawionej chorej, dlatego podjęto decyzję o długoterminowej terapii przeciwkrzepliwej. W przewlekłym leczeniu przeciwkrzepliwym szczególne miejsce zajmują NOAC, które - zapewniając optymalną skuteczność działania - zachowują wysoki profil bezpieczeństwa i wygody stosowania, dlatego stanowią ważna alternatywę dla antagonistów witaminy K. W wyborze leku przeciwkrzepliwego i doborze jego dawki u opisanej chorej kierowano się przede wszystkim obecnością czynników ryzyka zakrzepowo-zatorowego i ryzyka krwawienia, dostępnymi zaleceniami postępowania, wynikami przeprowadzonych badań, jak również preferencjami chorej. W badaniu ATLAS ACS-2 TIMI-51 (Anti-Xa Therapy to Lower Cardiovascular Events in Addition to Standard Therapy in Subjects with Acute Coronary Syndrome-Thrombolysis in Myocardial Infarction 51) wykazano, że stosowanie riwaroksabanu w małej dawce ( $5 \mathrm{mg}$ lub $10 \mathrm{mg} / \mathrm{d}$.) u chorych z ACS poddanych standardowej podwójnej terapii przeciwpłytkowej przyczynia się do redukcji częstości zgonów z przyczyn sercowo-naczyniowych, Ml i udaru mózgu w porównaniu ze stosowaniem placebo. $W$ trakcie leczenia zaobserwowano zależną od dawki większą częstość krwawień w grupie leczonej NOAC, niemniej jednak nie wykazano zwiększonego ryzyka krwawień zakończonych zgonem [10]. Chora prowadziła aktywny tryb życia i preferowała leki niewymagające regularnej kontroli INR, najchętniej dawkowane raz dziennie, dlatego ostatecznie podjęto decyzję o włączeniu riwaroksabanu. Dotychczas nie ustaIono optymalnej dawki tego leku w grupie chorych z ACS poddanych podwójnej terapii przeciwpłytkowej, zwłaszcza obciążonych trombofillią. Zważywszy na wysokie ryzyko nawrotu powikłań zakrzepowo-zatorowych oraz niskie ryzyko krwawienia zdecydowano o włączeniu riwaroksabanu w dawce $15 \mathrm{mg}$, a następnie $20 \mathrm{mg} /$ dobę. Potrójne leczenie 
przeciwzakrzepowe zalecono na okres 6 miesięcy, riwaroksabanem i klopidogrelem - przez kolejne 6 miesięcy, a po upływie 12 miesięcy - riwaroksabanem przewlekle.

\section{Podsumowanie}

Ostry zespół wieńcowy u pacjenta w młodym wieku powinien skłaniać do poszerzenia diagnostyki w kierunku chorób współistniejących, które są często dodatkowym czynni- kiem ryzyka powikłań zakrzepowo-zatorowych, zwłaszcza trombofilii. Właściwe rozpoznanie umożliwia wdrożenie optymalnego leczenia mającego na celu skuteczną prewencję wtórną zdarzeń sercowo-naczyniowych.

\section{Konflikt interesów}

Autorzy deklarują brak konfliktu interesów w związku z publikowaną pracą.

\section{Abstract}

A 31-year-old woman was admitted to the clinic due to severe chest pain. Based on the clinical status and additional tests results myocardial infarction with ST elevation was diagnosed. Urgent coronary angiography and occluded left anterior descending artery recanalization with drug eluting stent implantation were successfully performed and resulted in clinical improvement. Anamnesis revealed two prominent risk factors for atherosclerosis: hypertension and hypercholesterolemia. Laboratory blood test results revealed the presence of complex thrombophilia consisted of: hyperhomocysteinemia, MTHFR gene mutation, protein S deficiency and factor VIII excess. Due to the high risk of thromboembolic complications, rivaroxaban was added to the dual antiplatelet therapy. This case report demonstrates the importance of the determination of additional risk factors in secondary prevention of cardiovascular events in young patients.

Key words: myocardial infarction, complex thrombophilia, hyperhomocysteinemia, MTHFR gene mutation, protein S deficiency, anticoagulant therapy

Folia Cardiologica 2017; 12, 1: 96-102

\section{Piśmiennictwo}

1. Choudhury L, Marsh JD. Myocardial infarction in young patients. Am J Med. 1999; 107(3): 254-261, indexed in Pubmed: 10492319.

2. Rees DC, Cox M, Clegg JB. World distribution of factor V Leiden. Lancet. 1995; 346(8983): 1133-1134, indexed in Pubmed: 7475606.

3. Segev A, Ellis MH, Segev F, et al. High prevalence of thrombophilia among young patients with myocardial infarction and few conventional risk factors. Int J Cardiol. 2005; 98(3): 421-424, doi: 10.1016/j. ijcard.2003.10.057, indexed in Pubmed: 15708174.

4. Kim RJ, Becker RC. Association between factor V Leiden, prothrombin G20210A, and methylenetetrahydrofolate reductase C677T mutations and events of the arterial circulatory system: a meta-analysis of published studies. Am Heart J. 2003; 146(6): 948-957, doi: 10.1016/ /S0002-8703(03)00519-2, indexed in Pubmed: 14660985.

5. Botto N, Mariani M, Manfredi S, et al. A case report of myocardial infarction in young patient with a parental history of premature cardiovascular death: combination of prothrombotic gene mutations. Int J Cardiol. 2008; 130(1): e17-e19, doi: 10.1016/j.ijcard.2007.07.042, indexed in Pubmed: 17920139.
6. Xuan C, Bai XY, Gao Ge, et al. Association between polymorphism of methylenetetrahydrofolate reductase (MTHFR) C677T and risk of myocardial infarction: a meta-analysis for 8,140 cases and 10,522 controls. Arch Med Res. 2011; 42(8): 677-685, doi: 10.1016/j.arcmed.2011.11.009, indexed in Pubmed: 22154679.

7. Bloemenkamp KW, Helmerhorst FM, Rosendaal FR, et al. Venous thrombosis, oral contraceptives and high factor VIII levels. Thromb Haemost. 1999; 82(3): 1024-1027, indexed in Pubmed: 10494758.

8. Gerstman BB, Piper JM, Tomita DK, et al. Oral contraceptive estrogen dose and the risk of deep venous thromboembolic disease. Am J Epidemiol. 1991; 133(1): 32-37, indexed in Pubmed: 1983896.

9. Allaart CF, Aronson DC, Ruys T, et al. Hereditary protein S deficiency in young adults with arterial occlusive disease. Thromb Haemost. 1990; 64(2): 206-210, indexed in Pubmed: 2148653.

10. Mega JL, Braunwald E, Wiviott SD, et al. ATLAS ACS 2-TIMI 51 Investigators. Rivaroxaban in patients with a recent acute coronary syndrome. N Engl J Med. 2012; 366(1): 9-19, doi: 10.1056/ /NEJMoa1112277, indexed in Pubmed: 22077192. 